\title{
Effect of enzyme, multivitamin and growth promoter on growth performance and hemato-biochemical parameters in broiler chicken
}

\author{
Das MR ${ }^{1}$, Sarker MMH ${ }^{1}$, Rashid MB $^{2}$ and Miah MA ${ }^{1 *}$ \\ ${ }^{l}$ Department of Physiology, Bangladesh Agricultural University, Mymensingh-2202, Bangladesh. ${ }^{2}$ Department \\ of Physiology and Pharmacology, Hajee Mohammad Danesh Science and Technology University, Dinajpur.
}

[Received: February 02, Accepted: April 01, 2014]

\begin{abstract}
To investigate the effect of exogenous enzymes, multivitamin and growth promoter on growth performance and different hematobiochemical parameters of broilers, ten days old "Cobb 500" chicks were used and randomly divided into five equal groups (n=10). Group A was considered as control, fed only with commercial ration. Group B, C, D and E were supplemented with enzymes, multivitamin and enzymes plus multivitamin and growth promoter, respectively for the period of 21 days. Results revealed that body weight was increased significantly $(\mathrm{p}<0.05)$ in all four treated groups and highest body weight was recorded in group D. Weights of different organs except viscera (liver, spleen, skin, legs, breast meat, leg meat and viscera) were also varied significantly ( $p<0.05)$ among the treated groups. TEC increased significantly $(\mathrm{p}<0.05)$ in birds of all treated groups except group E whereas $\mathrm{Hb}$ concentration increased significantly $(\mathrm{p}<0.05)$ in all treated groups (B, C, D and E) as compared to control group A. Highest PCV was also recorded in group C but all the values were more or less similar and statistically insignificant $(\mathrm{p}>0.05)$. Biochemical parameters like AST were decreased significantly $(\mathrm{p}<0.05)$ in treated groups except group B and C. But, ALT values decreased significantly $(\mathrm{p}<0.05)$ in all treated groups in comparison to control group. It is concluded that combined supplementation of enzyme and multivitamin improved better in body weight and different organs weight gain and improves hemato-biochemical profile in broilers.
\end{abstract}

Key words: Hematology, biochemical profile, growth performance and broiler.

\section{INTRODUCTION}

The poultry industry in Bangladesh is becoming a leading industry and has immense potential for boosting the economic growth of the country as well as ensuring food security. Feed is an important factor for broiler production. Broiler diet is predominantly composed of plant materials, mainly cereals and vegetable proteins plus little amount of animal protein.( Many cereals and their byproduct contain non starch polysaccharides (NSP) such as cellulose, xylose, galactonic acid, arabinose which are not easily digested by poultry ${ }^{[1]}$. More over $70-80 \%$ phosphorus exist as phytate in the plant origin feed stuff and birds are unable to hydrolyze due to lack of necessary enzymes ${ }^{[2]}$. Most of the feed ingredients contain some anti-nutritional factors and nondigested part, which inhibit feed utilization and birds' performance. The anti-nutritive effect is manifested by depressed nutrient utilization accompanied by poor growth. This adverse effect can be overcome by supplementation of exogenous enzymes [3]. The main goals of enzyme supplementation to poultry diets are to remove or destroy the anti-nutritive factors of different feed ingredients; to enhance the overall digestibility of the feed; to render certain nutrients biologically more available; and to reduce pollution from animal excreta by reducing dry matter excretion ${ }^{[4]}$.Vitamin plays in important role in both nutrition and production. In comparison to other species, chickens are more susceptible to vitamin deficiency because gut flora can synthesize very little vitamins but compete with the host for dietary vitamins and intensively kept chickens undergo many stresses ${ }^{[5]}$. Inclusion of vitamin in the formulated diet has become indispensable practice because, feed ingredients do not contain all essential vitamins at the right amounts needed for chickens. Antibiotic growth promoter is used to destroy or inhibits bacteria and is administered at a low, sub therapeutic dose. Antibiotic growth promoter are used to "help growing animal digest their food more efficiently, get maximum benefit from it and allow them to develop into strong and healthy individuals helps to improve body weight" [6]. Growth promoters are now recognized in broiler industry as additives for faster growth and economic meat production. Growth promoters can play a vital role to shorten the time period required for attaining the market weight by stimulating growth. Since enzymes, multivitamins and growth promoters are claimed to improve the performance, so it would be interesting to conduct an experiment on the comparative growth performance of these products which help the farmers to select the appropriate product that is more potent growth promoter. Therefore, the study designed to observe the effect of enzyme, multivitamin and growth promoter supplementation on growth performance and hemato-biochemical parameters in broiler.

\section{MATERIALS AND METHODS}

Experimental birds, protocol and managements practices 
A total of 50, ten days old "Cobb 500" broiler chicks purchased from Alamin poultry farm, Chorkhai, Mymensingh were randomly divided into five equal groups $(n=5)$. Group A was considered as untreated control, fed only with commercial ration. Group B was supplemented with $1 \mathrm{~g}$ enzyme/liter drinking water. (Solzyme WS, Nuvista Animal Health and Crop Care Limited), Group C was supplemented with $0.5 \mathrm{~g}$ vitamin/ liter drinking water ( RenaWS, characteristics at the end of the experiment (31 days of age).

\section{Hemato-biochemical analysis}

Blood from each bird was collected during slaughter. A number of sterile test tubes containing anticoagulant (3.8\% Trisodium citrate solution) at a ratio of 1:10 were taken. The hematological studies were performed within two hours of collection.

Table 1. Effect of supplementation of enzyme, multivitamin and growth promoter on body weight $(\mathrm{mean} \pm \mathrm{SE})$ of broilers.

\begin{tabular}{ccccc}
\hline Group(N=10) & \multicolumn{4}{c}{ Body weight $(\mathrm{g})$} \\
\hline Group A & Day 0 & Day 7 & Day 14 & Day 21 \\
Group B & $342 \pm 16.21$ & $647 \pm 32.9^{\mathrm{a}}$ & $961 \pm 15.28^{\mathrm{a}}$ & $1246 \pm 22.55^{\mathrm{a}}$ \\
& $350 \pm 4.90$ & $866 \pm 13.3^{\mathrm{b}}$ & $1388 \pm 18.93^{\mathrm{b}}$ & $1884 \pm 21.59^{\mathrm{b}}$ \\
Group C & $343 \pm 9.07$ & $876 \pm 16.0^{\mathrm{b}}$ & $1390 \pm 16.17^{\mathrm{b}}$ & $1886 \pm 21.22^{\mathrm{b}}$ \\
Group D & $346 \pm 11.00$ & $889 \pm 16.4^{\mathrm{b}}$ & $1389 \pm 16.07^{\mathrm{b}}$ & $1914 \pm 17.56^{\mathrm{b}}$ \\
Group E & $344 \pm 28.52$ & $864 \pm 35.0^{\mathrm{b}}$ & $1376 \pm 115^{\mathrm{b}}$ & $1909 \pm 115.0^{\mathrm{b}}$ \\
\hline
\end{tabular}

Figures followed by different superscript letter in the same column differ significantly $(\mathrm{p}<0.05)$.

Renata), Group D was supplemented with enzyme and vitamin (RenaWS, Renata)combined at the same dose and Group E was supplemented with $0.5 \mathrm{~g}$ growth promoter/liter drinking water (Colistin 80, Veterinary and Agricultural products Mfg. Co. Ltd.) in addition to commercial ration. Initial body weight of each bird was recorded and kept them group wise. Fresh water was supplied to the broilers ad libitum. Feed supplementations were prepared on daily basis.
Sera were prepared for biochemical (AST and ALT) analyses according to standard procedures ${ }^{[7]}$. Briefly, $3 \mathrm{ml}$ of blood was collected in the sterile glass test tube. The blood containing tubes were placed in a slanting position at room temperature for clotting. Then the tubes were incubated overnight in the refrigerator $\left(4^{\circ} \mathrm{C}\right)$. Then serum was collected. The sample was centrifuged at $1000 \mathrm{rpm}$ for 15 minutes to have a more clear serum. The serum

Table 2. Effect of additional supplementation of enzyme, multivitamin and growth promoter on weight (mean \pm SE) of different organs of broiler.

\begin{tabular}{ccccc}
\hline Groups & Liver $(\mathrm{g})$ & Spleen $(\mathrm{g})$ & Breast meat $(\mathrm{g})$ & Leg meat $(\mathrm{g})$ \\
\hline Group A & $41 \pm 0.3^{\mathrm{a}}$ & $3.27 \pm 0.1^{\mathrm{a}}$ & $510 \pm 40.7^{\mathrm{a}}$ & $260 \pm 15.42^{\mathrm{a}}$ \\
Group B & $51 \pm 8.9^{\mathrm{b}}$ & $3.31 \pm 0.5^{\mathrm{a}}$ & $760 \pm 19.9^{\mathrm{b}}$ & $495 \pm 13.31^{\mathrm{b}}$ \\
Group C & $53 \pm 1.7^{\mathrm{b}}$ & $3.74 \pm 0.2^{\mathrm{b}}$ & $767 \pm 21.8^{\mathrm{b}}$ & $502 \pm 16.91^{\mathrm{b}}$ \\
Group D & $50 \pm 4.85^{\mathrm{b}}$ & $3.73 \pm 0.73^{\mathrm{b}}$ & $785 \pm 18.24^{\mathrm{c}}$ & $520 \pm 15.28^{\mathrm{c}}$ \\
Group E & $51 \pm 4.10^{\mathrm{b}}$ & $3.54 \pm 0.32^{\mathrm{ab}}$ & $780 \pm 15.00^{\mathrm{c}}$ & $516 \pm 9.02^{\mathrm{c}}$ \\
\hline
\end{tabular}

Figures followed by different superscript letter in the same column differ significantly $(\mathrm{p}<0.05)$.

Managements and rearing of birds were strictly followed according to standard broiler farming system. In order to prevent stress, shock, deficiencies and infections broiler chicks were routinely immunized and antibiotic premix were used as per recommendation of manufacturer. Proper hygienic and strict sanitary measures were also taken during the experimental periods.

\section{Measurements of body weight and organ weight of birds}

The body weight of each bird was measured with the help of electric balance on the day 10 of age ( 0 day of experiment). We used 10 days old chicks for management advantages and to reduce the mortality rate and subsequently compared the data with same age of untreated control birds. All the birds were sacrificed processed and weighed (liver, spleen, leg meat, breast meat, leg, skin and visceral) by electric balance to study the meat yield and growth samples were separated and stored at $-20^{\circ} \mathrm{C}$ till analysis. Serum transaminases were assayed by conventional enzymatic methods on a Hitachi 911 automated analyzer from Roche Diagnostics (Laval, QC, Canada) according to the manufacturer's specifications.

\section{Statistical analysis}

All data were presented as mean \pm standard error and differences among the groups of birds were compared using one-way ANOVA with post-hoc Duncan's multiple range test. Statistical analysis was performed using XLstat software.

\section{RESULTS AND DISCUSSION}

\section{Effects on body weight}

Body weight of different groups of birds is presented in Table 1 . Body weight on day 0 of experiment (day 10 of age) was more or less similar. On day 7, lower 
weight gain was recorded in birds of group A compared to others treated groups $(\mathrm{p}<0.05)$. On day 14 , the highest body weight gain was recorded in birds of group $\mathrm{C}$ which was significantly $(\mathrm{p}<0.05)$ higher than control group $(\mathrm{p}<0.05)$ and at the end of experiment, highest weight gain was recorded in birds of group D among the treated groups $(1914 \pm 17.56 \mathrm{~g})$ followed by E, C and B. It is evident that body weight increased significantly $(p<0.05)$ in all groups of birds with advancement of age. However in group A, body weight gain was slower compared to others treated group.

The increased body weight recorded in this experiment was consistent with the earlier reports ${ }^{[7-}$

10], those observed that vitamin and enzymes supplementation improved body weight gain and feed efficiency in broiler.

\section{Effects on weights of different selected organs}

The effects of enzyme and multi-vitamin and growth promoter on weights of different selected organs are presented in Table 2. The liver weight was recorded higher in all treated group with highest in group $\mathrm{C}$ compared to those of control group which was statistically significant $(\mathrm{P}<0.05)$. However, no significantly among the treated group with highest values found in group $\mathrm{C}$. The present finding differs with the earlier report that there was no significant effect of ascorbic acid and vitamin E supplementation on total erythrocyte count and $\mathrm{Hb}$ concentration $^{[11]}$.

Among the serum bio-chemical parameters, aspartate aminotransferase (AST) values were found significantly lower in treated groups except group B and $\mathrm{C}$ in comparison to control group. The decreased AST level in present finding resembles to previous reports ${ }^{[14]}$ which detected that AST level decreased significantly $(\mathrm{p}<0.05)$ with the increase level of vitamin and significantly higher AST values were observed in chicks that were not given supplemental vitamin. The lowest and statistically significant (ALT) alanine transaminase serum concentration was recorded in all treated groups. This finding differs with previous report that dietary vitamin A or E have no influence on alanine transaminase ${ }^{[15] .}$

Under the present experimental condition, it is concluded that supplementation of exogenous enzymes, multivitamins and growth promoter increases expected body growth and improves hemato-biochemical parameters in birds. However,

Table 3. Effect of additional supplementation of enzyme, multivitamin and growth promoter on hematological parameters (mean \pm SE) of broilers $(n=5)$.

\begin{tabular}{cccccc}
\hline Groups & TEC(millions $/ \mathrm{mm}^{3)}$ & $\mathrm{Hb}(\mathrm{g} / \mathrm{dl})$ & PCV $(\%)$ & AST(U/L) & ALT( U/L) \\
\hline Group A & $2.84 \pm 0.36^{\mathrm{a}}$ & $7.70 \pm 0.10^{\mathrm{a}}$ & $20.57 \pm 0.51^{\mathrm{a}}$ & $299 \pm 14.80^{\mathrm{a}}$ & $13.27 \pm 0.42^{\mathrm{a}}$ \\
Group B & $3.17 \pm 0.69^{\mathrm{b}}$ & $8.2 \pm 0.3^{\mathrm{b}}$ & $25.10 \pm 1.01^{\mathrm{b}}$ & $293 \pm 23.06^{\mathrm{a}}$ & $8.13 \pm 0.3^{\mathrm{b}}$ \\
Group C & $3.24 \pm 0.98^{\mathrm{b}}$ & $8.34 \pm 0.12^{\mathrm{b}}$ & $25.67 \pm 0.58^{\mathrm{b}}$ & $296 \pm 10.84^{\mathrm{a}}$ & $7.67 \pm 1.55^{\mathrm{b}}$ \\
Group D & $3.22 \pm 1.0^{\mathrm{b}}$ & $8.27 \pm 0.12^{\mathrm{b}}$ & $25.10 \pm 2.1^{\mathrm{b}}$ & $230 \pm 3.00^{\mathrm{c}}$ & $7.93 \pm 1.33^{\mathrm{b}}$ \\
Group E & $2.70 \pm 0.53^{\mathrm{a}}$ & $7.94 \pm 0.31^{\mathrm{ab}}$ & $25.03 \pm 1.00^{\mathrm{b}}$ & $265 \pm 13.07^{\mathrm{b}}$ & $7.4 \pm 0.70^{\mathrm{b}}$ \\
\hline
\end{tabular}

Figures followed by different superscript letter in the same column differ significantly $(\mathrm{p}<0.05)$

statistical significant was observed among the treated groups. The present finding is similar with the earlier experiment ${ }^{[11]}$. The highest spleen weight was recorded in group $\mathrm{C}$ and group $\mathrm{D}$. The finding is also similar with the earlier experiment which reported heavier spleen after vitamin supplementation to broiler chicks ${ }^{[12]}$.

Both breast meat weight and leg meat weight in birds of all treated groups were increased significantly $(\mathrm{p}<$ $0.05)$ compared to those of control group. However, breast and leg meat weight also varies among treated groups significantly $(\mathrm{p}<0.05)$. The present finding is consistent with that of findings of previous report that higher breast weight gain in birds after vitamin supplementation ${ }^{[13]}$.

\section{Effects on haemato-biochemical parameters}

The effects of dietary supplementation of enzymes, multivitamins and growth promoter on hematobiochemical parameters are presented in table 3 . Increased total erythrocyte count (TEC) was observed in birds of group C followed by group D and $B$ which was statistically significant $(p<0.05)$ compared to control group. Similarly, the values of $\mathrm{Hb}$ concentration and PCV were increased
Inclusion of both enzyme and multivitamins in feed showed better improvement than growth promoter. Further study with more experimental birds are needed to make final conclusion.

\section{REFERENCES}

1. Alam MJ 2001: Effect of exogenous enzyme in diet on broiler performance. M.S. Thesis, Dept. of Poultry Science, BAU, Mymensingh2202.

2. Kies AK, Vanhemert KAF, Sauer WC 2001: Effect of phytase on protein and amino acid digestibility and energy utilization. World's Poultry Science Journal 57 109-124.

3. Bedford MR 1995: Mechanism of action and potential environmental benefits from the use of feed enzymes. Animal Feed Science and Technique 53 145-155.

4. Toghyani M, Mohammadsalehi A, Gheisari A, Tabeidian SA 2009: The effect of lowglucosinolaterapeseed meal in diets with multi-enzyme supplement on performance and 
protein digestibility in broiler chicks. Journal of Animal and Feed Science 18(2) 313-321.

5. Ward NE 1996: Commercial vitamin supplementation for poultry. Poultry Adviser, New Jersey, USA. 29(3) 29-50.

6. Lee DN, Ching FW, Shiau-RUL, Hen WW 2008: Effect on growth performance immune response and gastrointestinal health of Taiwan red feathered native chickens feed diets supplementation with growth promoting antibiotics. Journal China Social Animal Science 37 223-224.

7. Salahuddin M, Miah MA, Ahmad N 2012: Effect of protein and vitamin A, D, E on growth performance and hemato-biochemical parameters on broiler. Bangladesh Journal of Veterinary Medicine 10 (1-2) 10-14.

8. Downs KM, Norton RA, Maclin KS, Hess JB 2003: Potential of vitamin $\mathrm{E}$ and zinc-amino acid complex for the reduction of cellulitis in broilers. Journal of Applied Animal Research. 23(1) 25-32.

9. Hosamani SV, Shivakumar MC, Kulkarni VS, Harapanahalli MD 2001: Effect of supplementing dietary enzyme on the performance of broilers. Karnataka Journal of Agricultural Sciences 14(4) 1046-1048.

10. Villar PG, Diaz CA, Avila GE, Guinzberg R, Pablos JL, Pina E 2000: Effects of dietary supplementation with vitamin $\mathrm{C}$ or vitamin $\mathrm{E}$ growth performance in broilers at risk of developing ascites syndrome. American Journal of Veterinary Research 63(5)673-676.

11. Shlig AA 2009: Effect of vitamin E and selenium supplement in reducing aflatoxicosis on performance and blood parameters in broiler chicks. Iraqi Journal of Veterinary Sciences 23 97-103.

12. Singh H, Sodhi S, Kaur R 2006: Effects of dietary supplements of selenium, vitamin $\mathrm{E}$ or combinations of the two on antibody responses of broilers. Poultry Science 47(6) 714-719.

13. Choct M, Naylor AJ 2004: Effect of dietary selenium and vitamin $\mathrm{E}$ levels on performance of male broilers. Asian Australia Journal of Animal Science 17 1000-1006.

14. Swain BK, Johri TS, Majumdar S 2000: Effect of supplementation of vitamin $\mathrm{E}$, selenium and their different combinations on the performance and immune response of broilers. Poultry Science 41(3) 287-292.

15. Sahin N, Sahin K, Kucuk O 2001: Effects of vitamin $\mathrm{E}$ and vitamin A supplementation on performance, thyroid status and serum concentrations of some metabolites and minerals in broiler reared under heat stress $\left(20^{\circ} \mathrm{c}\right)$. Veterinary Medicine 46(11-12) 286292. 